MS27 P01

((Z)-Ethyl

4-chloro-3-oxo

$-2-(2-p-$

tolylhydrazono)butanoate Ahmet Erdönmez ${ }^{\mathrm{a}}$, Gökhan Alpaslan ${ }^{\mathrm{a}}$, Mustafa Odabaşoğlu ${ }^{\mathrm{b}}$, Özgür Özdamar ${ }^{\mathrm{b}}$, Nazan Ocak İskeleli ${ }^{\mathrm{a}}$, ${ }^{a}$ Ondokuz Mayls Univ., Department of Physics, Samsun-Turkey. ${ }^{b}$ Ondokuz Mayls Univ., Department of Chemistry, Samsun-Turkey.

E-mail: erdonmez@omu.edu.tr

Keywords: Single-crystal X-ray study; Keto-hydrozo tautomeric form, aliphatic chain

(Z)-Ethyl 4-chloro-3-oxo -2-(2-ptolylhydrazono]butanoate $\quad\left(\mathrm{C}_{13} \mathrm{H}_{15} \mathrm{ClN}_{2} \mathrm{O}_{3}\right) \quad$ was synthesized and its crystal structure determined. It crystallizes in the monoclinic space group, $\mathrm{P} 2{ }_{1} / \mathrm{n}$, with $\mathrm{a}=$ 7.2025(4), $\mathrm{b}=19.3625(14), \mathrm{c}=10.6093(6) \AA, \mathrm{R}\left(\mathrm{F}^{2}\right)=$ 0.034 for 2743 independent reflections.

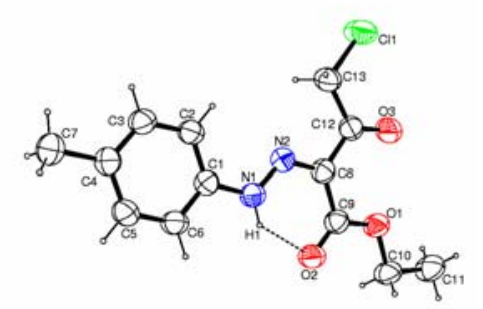

[The title compound, $\left(\mathrm{C}_{13} \mathrm{H}_{15} \mathrm{ClN}_{2} \mathrm{O}_{3}\right)$, adopts a ketohydrazo tautomeric form, stabilized by an intramolecular hydrogen bond. The configuration around the N-N bond is trans.

\section{MS27 P02}

Tetrahedral ligands as Nodes for MOF Frameworks

Bettinah K.M Chipimpi, Martin W. Bredenkamp, Leonard J. Barbour, Department of Chemistry,University of Stellenbosch, 7602 Maitland, South Africa.

E-mail:munsakac@sun.ac.za

\section{Keywords: MOF's, porosity, gas sorbtion}

Porous Crystalline materials [1] are of significant interest for their host/guest properties, especially with regard to the sorption and stabilization of gas molecules. We are interested in the formation of porous network structures based on a variety of new ligand systems. To this end we are currently investigating MOF's constructed from multitopic rigid tetrahedral ligands derived from tetraphenyl methane. We reveal the MOF crystal structures of tetrakis[4-(2-phenylthiazol-4yl)phenyl]methane [2] with various metal salts.We have also investigated the ability of these materials to absorb a variety of small gas molecules.

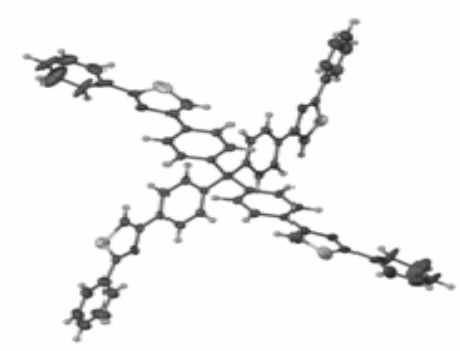

[1] L. J Barbour, Chem. Commun, 2006, 1163.

[2] T.J Zimmermann and T. J. Müller, Synthesis, 2002, 9, 1157.

\section{MS27 P03}

Structures And Electrochemical Studies of schiff bases derivatives from DHA A. Djedouani ${ }^{\mathrm{a}}$, A. Bendaas ${ }^{\mathrm{a}}, \mathrm{H}$. Mousser ${ }^{\mathrm{b}}$, A. Mousser ${ }^{\mathrm{c}}{ }^{a}$ Laboratoire d'Electrochimie des Matériaux Moléculaires et Complexes, Université Farhat Abbés de Sétif. DZ 1900 Sétif Algeria. ${ }^{b}$ Département de Chimie Industrielle,Université Mentouri Constantine, ${ }^{\mathrm{c}}$ Département de Chimie,Université Mentouri Constantine. E-mail: Djed_amelle@yahoo.fr.

Keywords : Schiff base, Zwitterionic , Cyclic voltammetry.

Schiff bases are widely used as ligands to coordinate various metal ions because of the good solubility of their complexes [1]. These compounds contain several donor atoms and have potential application in water treatment, due to their ability to readily form transition metals complexes [2]. These complexes species are also involved in enzymatic reaction and present in proteins from conjunctive tissu. They can also be used as selective membranes or as corrosion prevent compounds [3]. Our work is dedicated for the synthesis, characterisation and electrochemical study survey of new schiff bases, derivative from dehydroacetic acid (DHA : : 3-Acetyl-6methyl-2H-Pyran-2,4(3H)-dione). and anilin and 4-chloro aniline respectively : (L1)=(E)-6-methyl-2-oxo-3-[1-(pchloriminio)ethyl]-2H-pyran-4-olate, and $\mathrm{L} 2=(\mathrm{E})-6-$ methyl-2-oxo-3-[1-(iminio)ethyl]-2H-pyran-4-olate. These two products were characterised by usual spectroscopic methods so as IR, NMR, and RX. L(1), has the following structural properties : Monoclinic, $\mathrm{P} 2{ }_{1} / \mathrm{c}, \mathrm{a}=11.8933(5) \AA$, $\mathrm{b}=7.9260(3) \AA, \mathrm{c}=12.9177(7) \AA, \beta=91.2598(14)^{\circ}$, and $Z=4$; for $L(2) a=7.561(5), b=8.738(7), c=10.209(12)$, $\alpha=85.018(4)^{\circ}, \beta=79.311(3)^{\circ}, \gamma=76.008(8)$ and $Z=2$. The two molecules have a zwitterionic form with cationic iminium and anionic enolate groups [4].

An electrochemical study, by cyclic voltammetry for the two compond, has been achieved in aprotic medium, DMF-TBAHFB $0.1 \mathrm{M}$, on a platin electrode of $2 \mathrm{~mm}$ of diameter. A cyclic sweep in the -1.8 to $+1.8 \mathrm{~V}$ range shows for (L1) an anodic peak at $1.43 \mathrm{~V}$ and two cathodic peaks at $-0.717 \mathrm{~V}$ and $-0.149 \mathrm{~V}$. in the case of the (L2) and anodic peak at $0.13 \mathrm{~V}$ and a cathodic peak appears at $0.147 \mathrm{~V}$.

[1] A.Ramachandraich, P.Nageswara Rao et M.Ramaiah. Indian Journal of Chemistry. 28 (1989) 309-313.

[2] Eva-Franco, Elena Lopez-Torres, M.Antonia Mendialoey M.Teresa Sevela. Polyhedron 19 (2000) 441-451.

[3] Hassan Kaypour, Sadegh et R.V.Parish. Molécules 7 (2002) 140-144.

[4] A. Djedouani, A. Bendaas, S. Boufas, M. Allain, G.Bouet and M. Khan Acta Cryst. E63 (2007)., o1271-o1273. 